\title{
PENILAIAN USER EXPERIENCE FIORI BUSSIM MENGGUNAKAN USER EXPERIENCE QUESTIONAIRE (UEQ) DAN PENGARUHNYA TERHADAP PEMAHAMAN PEMBELAJARAN MATAKULIAH SERTIFIKASI SAP
}

\author{
Fandi Halim ${ }^{1)}$, Handoko ${ }^{2)}$, dan Sophya Hadini Marpaung ${ }^{3)}$ \\ 1,2,3 Program Studi Sistem Informasi, STMIK Mikroskil \\ 1,2,3 Jl. Thamrin No 140, Medan, 20212 \\ E-mail : fandi@mikroskil.ac.id ${ }^{1)}$, handoko.wu@mikroskil.ac.id ${ }^{2)}$, sophya.marpaung@ mikroskil.ac.id ${ }^{3)}$
}

\begin{abstract}
ABSTRAK
Penelitian ini menggunakan User Experience Questionaire (UEQ) dalam menilai pengalaman pengguna dari FIORI Bussim dan dilanjutkan dengan menilai pengaruh dari pengalaman penggunaan FIORI Bussim itu sendiri terhadap tingkat pemahaman dari mahasiswa/i dalam memahami proses bisnis yang terintegrasi dengan perangkat lunak SAP (System Application and Product in Data Processing) pada mahasiswa. Secara rinci, kegiatan penelitian akan dilaksanakan dalam beberapa tahapan yaitu mengevaluasi kembali dan menetapkan perumusan masalah yang akan diselesaikan, melakukan studi literatur, pengumpulan data, penilaian dan konstruksi kuesioner untuk menilai pengalaman penggunaan FIORI Bussim dan pengaruhnya terhadap tingkat pemahaman penggunaan oleh pengguna yang dapat disebut sebagai tahapan post-condition, melakukan analisis dan pengujian dan mengambil kesimpulan. Hasil pengujian pada penelitian ini menggunakan User Experience Questionaire (UEQ) pada SAP-GUI (Graphical User Interface) dan FIORI Bussim dengan jumlah responden yang terlibat pada pengujian adalah sebanyak 132 orang mahasiswa yang menunjukkan hasil bahwa nilai pengalaman penggunaan FIORI Bussim lebih baik daripada SAP-GUI. Selanjutnya, nilai pengujian pada penelitian ini terhadap domain pemahaman yang dilihat dari beberapa domain yaitu domain kognitif, afektif dan psikomotorik menunjukkan bahwa lebih banyak responden yang mengalami penurunan dibandingkan peningkatan positif. Dengan demikian dapat disimpulkan bahwa pengalaman penggunaan dari FIORI Bussim ternyata tidak serta merta membuat tingkat pemahaman terhadap proses bisnis dalam SAP menjadi lebih baik.
\end{abstract}

Kata Kunci: Pengalaman Pengguna, Pemahaman Pengguna, Ueq, Pembelajaran, Sap.

\section{PENDAHULUAN}

Berikut Sesuai dengan UU Ketenagakerjaan Nomor 13 Tahun 2003 dan Peraturan Presiden Nomor 8 Tahun 2012 tentang Kerangka Kualifikasi Nasional Indonesia dan Peraturan Menteri Tenaga Kerja Nomor 5 Tahun 2012 tentang sistem standarisasi kompetensi kerja nasional menunjukkan bahwa pentingnya mempersiapkan kompetensi untuk mahasiswa melalui uji kompetensi yang mengacu pada standar tertentu. Mempersiapkan hal ini, sebuah lembaga pendidikan dapat secara mandiri memiliki lembaga sertifikasi atau dapat bekerja sama dengan lembaga kompetensi yang sudah ada untuk mendukung kepastian sumber daya manusia yang handal dan dipercaya, misalnya melalui program sertifikasi internasional penguasaan perangkat lunak seperti Microsoft, DB2 SAP dan sebagainya.

Menyikapi hal di atas, Program Studi S-1 Sistem Informasi dari tahun 2012 telah melakukan pembenahan kurikulum sembari menjalin kerja sama dengan mitra SAP di bidang edukasi yakni edugate untuk mengintegrasikan program sertifikasi SAP pada kurikulum. SAP (Systems, Applications, and Products in Data Processing) adalah perangkat lunak Enterprise Resource Planning (ERP) yang mengintegrasikan proses bisnis pada perusahaan. Setiap mahasiswa pada program studi S-1 sistem informasi wajib mengikuti mata kuliah pengantar ERP (SAP01 - SAP Overview) pada semester ganjil yang bertujuan memberikan pengenalan awal terhadap perangkat lunak SAP dan bagaimana perangkat lunak SAP terintegrasi dalam setiap proses bisnis dalam perusahaan. Dalam pelaksanaan matakuliah ini, selain daripada penggunaan perangkat lunak SAP, Edugate juga mempersiapkan sebuah sistem berbasis web yang digunakan sebagai perangkat lunak simulasi bisnis dengan konsep penggunaan yang mirip dengan perangkat lunak SAP yang disebut sebagai FIORI Bussim. FIORI Bussim diklaim memiliki cara penggunaan dan tampilan antar muka yang lebih sederhana dibandingkan dengan perangkat lunak SAP yang lebih rumit dan lengkap. Hal ini ditujukan untuk membantu pemahaman mahasiswa/i yang mengikuti matakuliah pengantar ERP tentang proses bisnis yang terdapat dalam perangkat lunak SAP. Penelitian ini dilakukan untuk menilai sejauh mana tingkat efektifitas FIORI Bussim yang diklaim lebih sederhana dalam sisi tampilan antar muka pengguna dapat membantu meningkatkan pemahaman dari mahasiswa/i dalam memahami proses bisnis yang terintegrasi dalam perangkat lunak SAP. 
"What is Usable is Beautiful", sebuah kalimat yang dicetuskan dalam sebuah judul penelitian oleh Tractinsky et al. (2000) mendeskripsikan bahwa terdapat hubungan yang erat antara persepsi awal dari pengguna sistem tentang estetika antara muka dan persepsi mereka tentang usabilitas sistem. Melalui kalimat tersebut, tractinsky et al. (2000) meyakini bahwa terdapat peran dari estetika dalam desain antara muka pengguna dan dampaknya terhadap pengalaman pengguna dalam interaksinya dengan sistem terkomputerisasi. Hal ini kemudian menjadi salah satu ide dasar Rauschenberger (2013) untuk melakukan konstruksi sebuah alat bantu pengukuran pengalaman pengguna yang dinamakan User Experience Questionaire (UEQ). UEQ dapat digunakan untuk menilai pengalaman pengguna untuk setiap jenis produk interaktif (Raunschenberger, 2013).

Penelitian ini menggunakan UEQ dalam menilai pengalaman pengguna dari FIORI Bussim dan dilanjutkan dengan menilai pengaruh dari pengalaman penggunaan FIORI Bussim terhadap tingkat pemahaman dari mahasiswa/i dalam memahami proses bisnis yang terintegrasi dalam perangkat lunak SAP.

\section{RUANG LINGKUP}

Permasalahan yang diangkat dalam penelitian ini.

1. Apakah terdapat peningkatan pemahaman terhadap perangkat lunak SAP setelah penggunaan FIORI Bussim

2. Apakah terdapat pengaruh dari pengalaman penggunaan FIORI Bussim terhadap tingkat pemahaman mahasiswa/i dalam memahami proses bisnis yang terintegrasi dalam perangkat lunak SAP

Fokus daripada penelitian ini adalah pada pengalaman pengguna yang dalam hal ini adalah mahasiswa/i dalam menggunakan FIORI Bussim dan pengaruhnya terhadap tingkat pemahaman mahasiswa/i terhadap proses bisnis yang terintegrasi dalam perangkat lunak SAP.

\section{BAHAN DAN METODE} ini.

Disajikan kajian teori dan metode dalam penelitian

\subsection{User Experience Questionaire (UEQ)}

Pengalaman pengguna merupakan perasaan subjektif yang dirasakan oleh pengguna terhadap sebuah produk yang sedang digunakan. Pengguna yang berbeda tentu akan memiliki pengalaman yang berbeda walaupun hal itu adalah untuk sebuah produk yang sama. Hal ini yang membuat menilai pengalaman pengguna membutuhkan penilaian dari sekolompok besar pengguna karena dengan semakin besar jumlah pengguna yang menilai maka feedback (umpan balik) yang didapatkan juga akan semakin lengkap dan beragam. (Laugwitz et al, 2008).

Menilai pengalaman pengguna dengan target penilai dalam jumlah yang besar tentu akan lebih efisien jika menggunakan kuesioner terutama berbasis online. Dalam melakukan penilaian terhadap pengalaman pengguna, salah atu alat bantu yang dapat digunakan adalah User Experience Questionaire (UEQ) oleh Laugwitz et al, (2008). Konstruksi User Experience Questionaire (UEQ) memiliki 6 (enam) skala pengukuran dengan 26 item di dalamnya. (Rauschenberger et al. ,2013)

1. Attractiveness - berkaitan dengan kesan pertama terhadap sebuah produk. Terkait tingkat kesukaan pengguna terhadap produk. skala ini adalah dimensi yang meliputi beberapa item yakni: annoying/enjoyable, good/bad, unlikable / pleasing, unpleasant / pleasant, attractive / unattractive, friendly / unfriendly.

2. Efficiency - berkaitan dengan kemungkinan untuk menggunakan produk dengan cepat dan efisien dan apakah tampilan antarmuka kelihatan terorganisir dengan baik dengan dimensi yang meliputi beberapa item yakni: fast/slow; inefficient, impractical /practical, organized/cluttered.

3. Perspicuity - berkaitan dengan kemudahan pemahaman tentang cara menggunakan produk dan kemudahan untuk menjadi akrab dengan produk dengan dimensi yang meliputi beberapa item yakni: not understandable/understandable, easy to learn / difficult to learn, complicated/easy, clear/confusing.

4. Dependability - berkaitan dengan apakah user memiliki rasa mengendalikan interaksi ketika menggunakan dan apakah interaksi dengan produk aman dan dapat diprediksi dengan dimensi yang meliputi beberapa item yakni: unpredictable/predictable, obstructive/supportive, secure/not secure, meets expectations/does not meet expectations.

5. Stimulation - berkaitan dengan apakah menarik untuk menggunakan produk dan apakah pengguna merasa termotivasi untuk menggunakan produk lebih jauh dengan dimensi yang meliputi beberapa item yakni: valuable/inferior, boring/exciting, not interesting/interesting, motivating/demotivating

6. Novelty - berkaitan dengan apakah rancangan produk inovatif dan kreatif dan apakah produk menarik perhatian pengguna dengan dimensi yang meliputi beberapa item yakni: creative/dull, inventive/conventional, usual/leading edge, conservative/innovative.

Dependensi dari skala UEQ memperhatikan kualitas pragmatis dan kualitas hedonic. Perspicuity, effiiciency dan dependability adalah goal-oriented yang dalam hal ini adalah aspek kualitas pragmatis. Stimulation dan Novelty adalah non goal-oriented yang dalam hal ini merupakan aspek kualitas hedonik. Adapun model dapat dilihat pada gambar 1 (Rauschenberger et al., 2013). 


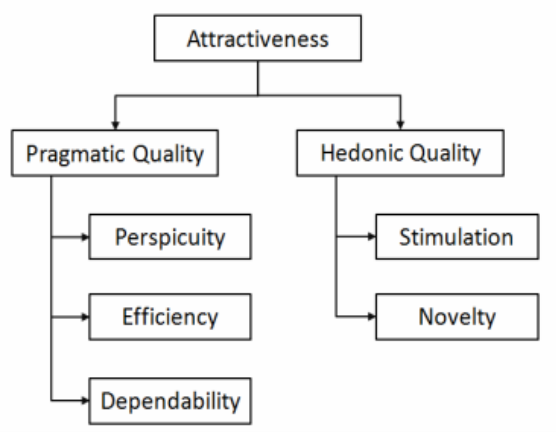

Gambar 1. Struktur Skala dari Kuesioner UEQ

Secara spesifik, urutan kuesioner UEQ untuk urutan item dan orientasinya (dimulai dari positif atau pernyataan antonim) diacak. Kuesioner UEQ telah dikonstruksi dalam berbagai bahasa yang salah satunya adalah bahasa Indonesia oleh Santoso et al. (2016). Bentuk dari kuesioner UEQ dalam bahasa Indonesia dapat dilihat pada gambar 2 (Santoso et al., 2016)

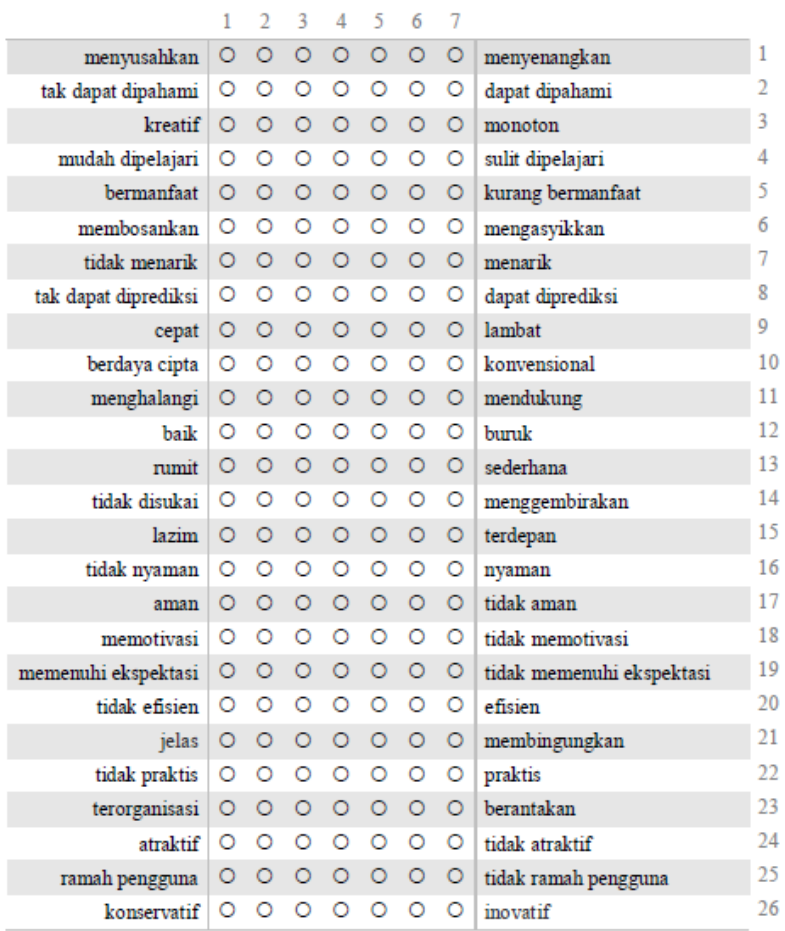

\section{Gambar 2. Kuesioner UEQ dalam Bahasa Indonesia}

\subsection{Domain Pembelajaran}

Pembelajaran adalah sebuah proses yang secara umum dapat dikategorikan ke dalam tiga domain: cognitive, affective dan psychomotor. Pada setiap domain terdapat berbagai level pembelajaran yang menunjukkan kemajuan dari basic-level, surface-level learning hingga ke level yang lebih kompleks, dan deeper level. Taksonomi kognitif telah mulai dikenal dari tahun 1956. Taksonomi afektif mulai dikenal dari tahun 1964 dan terakhir taksonomi psikomotor mulai dideskripsikan tetapi belum sepenuhnya dari tahun 1970 (Hoque, 2016).
Penjelasan yang lebih rinci tentang setiap domain dapat dijabarkan.

1. Domain Kognitif

Domain kognitif mencakup kemampuan pembelajaran terutama yang berkaitan dengan proses berpikir. Bloom's taxonomy awalnya mengenalkan bahwa terdapat 6 (enam) level tingkat kompleksitas kognitif yang meliputi: knowledge, comprehension, application, analysis, synthesis dan evaluation (Hoque, 2016).

2. Domain Afektif

Domain afektif meliputi perasaan, emosi dan sikap. Domain ini meliputi cara menghadapi sesuatu ditinjau dari aspek emosional. Domain ini dapat dikategorikan menjadi 5 (lima) sub domain yang meliputi: (1) receiving, (2) responding, (3) valuing, (4), organization, dan (5) characterization. (Hoque, 2016)

3. Domain Psikomotor

Domain psikomotor merepresentasikan fungsi fisik, aksi reflek dan pergerakan untuk menjelaskan sesuatu (interpretive).

\subsection{Penelitian Terdahulu}

Beberapa penelitian terdahulu telah menggunakan UEQ untuk melakukan pengukuran pengalaman pengguna dalam penggunaan sistem atau aplikasi di berbagai bidang. Salah satunya Sularsa et al. (2015) yang menggunakan UEQ untuk mengevaluasi produk aplikasi idigital museum. Idigital museum merupakan prototipe sistem penyajian koleksi museum dalam media digital. Pengunjung museum dapat berinteraksi dengan penyajian koleksi yang lebih menarik dan komprehensif dengan memanfaatkan teknologi. Pada penelitiannya Sularsa et al (2015), dengan menggunakan UEQ untuk mengevaluasi pengalaman penggunaan aplikasi interaktif danau bandung purba tersebut.

UEQ juga ikut digunakan dalam mengevaluasi sistem atau aplikasi dalam bidang pendidikan. izabal et al. (2018) juga menggunakan UEQ dan Focus Group Discussion (FGD) untuk melakukan evaluasi dan perbaikan terhadap situs web FILKOM Apps Mahasiswa pada fakultas ilmu komputer di Universitas Brawijaya. UEQ digunakan izabal et al. (2018) untuk mengevaluasi pengalaman penggunaan website FILKOM Apps mahasiswa. Santoso et al. (2016) juga menggunakan UEQ untuk mengukur pengalaman pengguna situs $e$ learning pada student-centered learning dengan melibatkan 213 responden yang merupakan mahasiswa dari jurusan ilmu komputer Universitas Indonesia.

UEQ juga digunakan untuk mengevaluasi aplikasi di bidang bisnis. Lukita et al. (2018) menggunakan UEQ untuk menilai pengalaman pengguna yang dalam hal ini adalah pelanggan yang berbelanja di Nappa Milano Online Store. Untuk diketahui Nappa Milano online store adalah situs online yang menjual sepatu pria dengan merk Nappa Milano yang sudah ada sejak tahun 2013. Adinegoro et al. (2018) juga menggunakan UEQ 
untuk menilai pengalaman penggunaan website $E$ commerce dengan menggunakan UEQ dan usability testing dengan studi kasus pada Lazada.co.id, Blibli.com, dan JD.id.

\subsection{Metode Penelitian}

Kegiatan penilaian secara keseluruhan dapat dimodelkan dengan gambar 3.

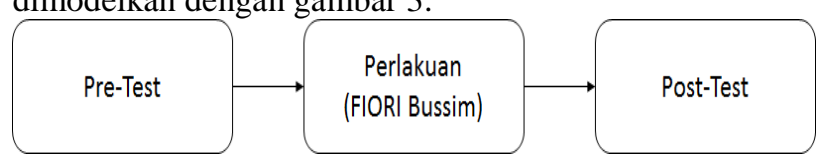

Gambar 3. Tahapan Penelitian

Secara rinci, kegiatan penelitian akan dilaksanakan dalam beberapa tahapan.

1. Tahapan awal dari penelitian adalah mengevaluasi kembali dan menetapkan perumusan masalah yang akan diselesaikan di dalam penelitian ini. Perumusan masalah ini akan dirumuskan berdasarkan latar belakang, permasalahan, serta ruang lingkup sejauh mana masalah ini akan diteliti.

2. Melakukan studi literatur untuk mengetahui lebih lanjut penelitian sejenis yang telah dilakukan terutama yang berkaitan dengan pengalaman pengguna (User Experience) dan pemahaman penggunaan

3. Melakukan pengumpulan data dengan mulai merancang kuesioner untuk menilai pemahaman penggunaan saat sebelum menggunakan FIORI Bussim untuk tahapan pre-condition. Kuesioner akan disebarkan kepada seluruh mahasiswa/i program studi S-1 Sistem Informasi yang mengikuti perkuliahan Pengantar ERP (SAP01Fundamental) untuk semester ganjil tahun ajaran 2019/2020.

4. Melakukan penilaian dan konstruksi kuesioner untuk menilai pengalaman penggunaan FIORI Bussim dan pengaruhnya terhadap tingkat pemahaman penggunaan oleh pengguna yang dapat disebut sebagai tahapan post-condition. Kuesioner akan disebarkan kembali kepada seluruh mahasiswa/i program studi S-1 Sistem Informasi yang mengikuti perkuliahan Pengantar ERP (SAP01-Fundamental) untuk semester ganjil tahun ajaran 2019/2020.

5. Melakukan analisis dan pengujian dan mengambil kesimpulan. Kemudian berdasarkan hasil yang didapatkan akan disusun laporan akhir penelitian sebagai hasil akhir penelitian. penelitian terdahulu telah menggunakan UEQ untuk melakukan pengukuran pengalaman pengguna dalam penggunaan sistem atau aplikasi di berbagai bidang. Salah satunya Sularsa et al. (2015) yang menggunakan UEQ.

\section{PEMBAHASAN}

Observasi terhadap SAP GUI dan FIORI Bussim dan dilanjutkan dengan analisis pengalaman penggunaan SAP GUI dan FIORI Bussim serta analisis uji komparatif untuk domain pemahaman.

\subsection{Observasi SAP GUI}

Observasi terkait SAP GUI berbasis desktop ini dimulai dari tampilan-tampilan antarmuka yang ada pada SAP GUI itu sendiri.

\section{Tampilan Halaman Login - SAP GUI}

Halaman login pada Gambar 4 merupakan halaman pertama yang akan disuguhkan kepada pengguna ketika hendak menggunakan aplikasi SAP ini. Pada halaman ini pengguna diminta untuk mengisikan nomor client, user dan password yang digunakan untuk masuk ke menu utama

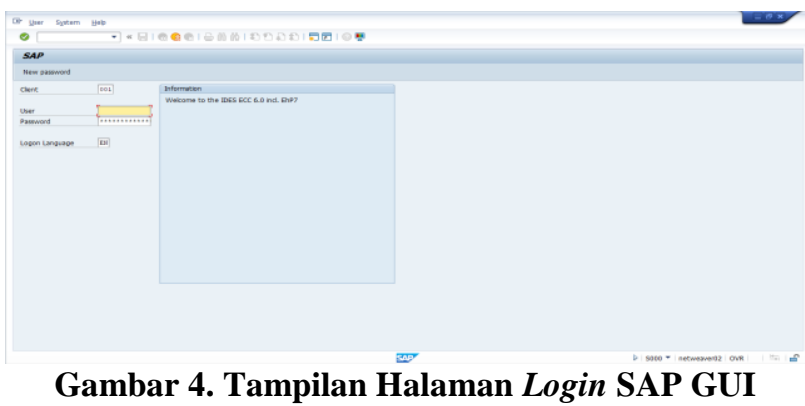

2. Tampilan Transaksi Create Purchase Order

Tampilan Transaksi Create Purchase Order pada gambar 5 adalah tampilan contoh/sample transaksi create PO/ purchase order pada aktivitas pengadaan/procurement.

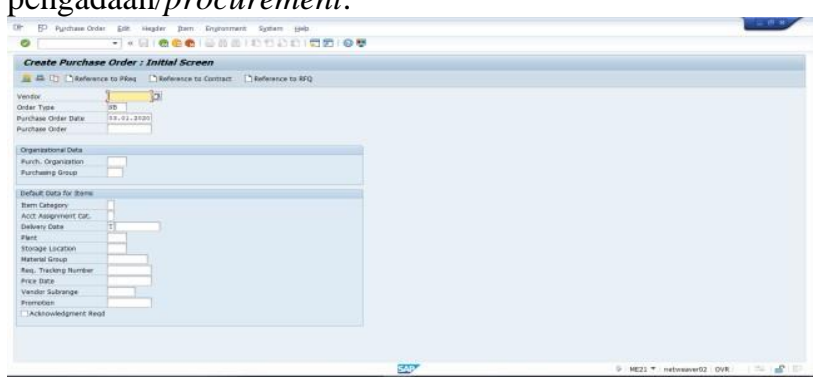

Gambar 5. Tampilan Transaksi Create Purchase Order - SAP GUI

3. Tampilan Transaksi Display Billing Document

Tampilan Transaksi Display Billing Document pada gambar 6 adalah tampilan contoh/sample transaksi pada menu accounting yang menampilkan billing document yang pernah digunakan pada satu atau lebih transaksi di SAP GUI. 


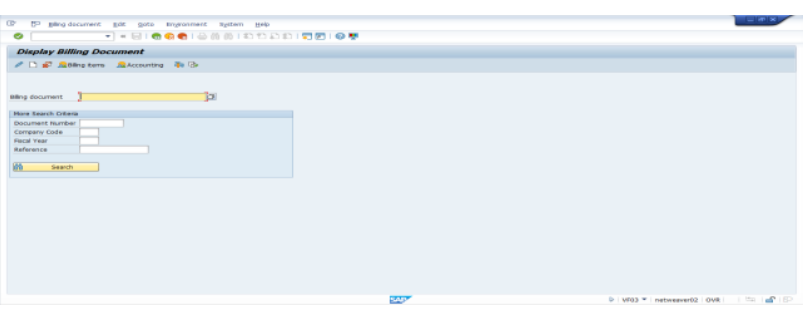

Gambar 6. Tampilan Transaksi Display Billing Document - SAP GUI

\subsection{Observasi FIORI Bussim}

Observasi terkait FIORI Bussim yang dijalankan dengan sistem berbasis web ini juga dimulai dari penjelasan antarmuka pengguna di masing-masing halaman transaksi yang ada di SAP dan FIORI Bussim. adapun berikut uraiannya adalah sebagai berikut:

1. Tampilan Halaman Login - FIORI

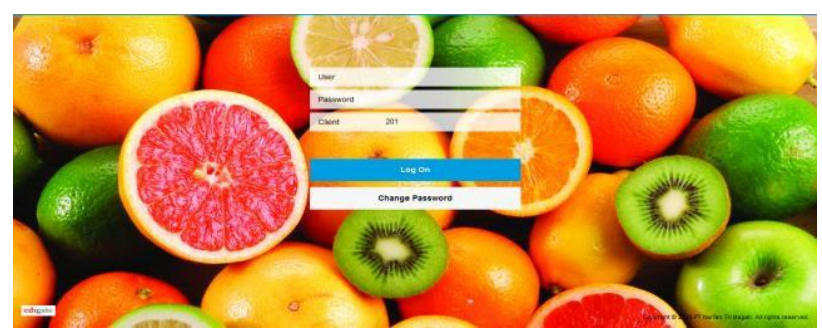

Gambar 7. Tampilan Halaman Login FIORI Bussim

Gambar 7 merupakan halaman login pada FIORI Bussim memiliki field isian yang sama dengan field isian login pada SAP GUI. Pada halaman ini, pengguna juga diminta untuk mengisikan nama user, password, dan client yang digunakan untuk masuk ke menu utama di FIORI Bussim.

\section{Tampilan Transaksi Create Purchase Order -} FIORI

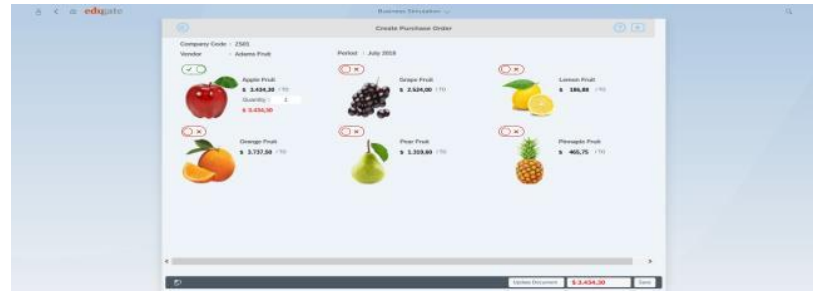

Gambar 8. Tampilan Transaksi Create Purchase Order - FIORI Bussim

FIORI Bussim memiliki tampilan Purchase Order yang sangat berbeda dengan versi desktop SAP GUI dapat dilihat seperti pada gambar 8
3. Tampilan Transaksi Display Billing Document FIORI

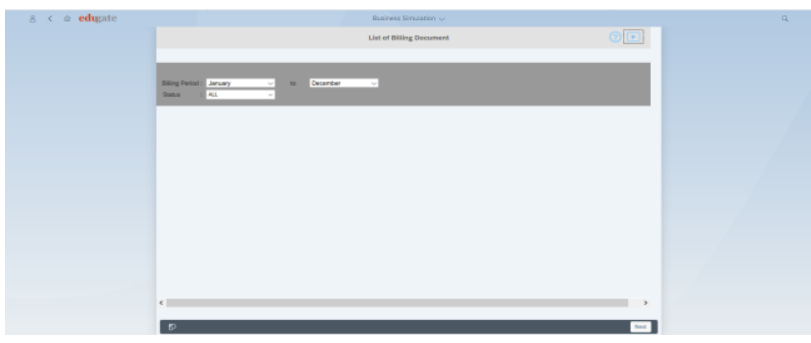

Gambar 9. Tampilan Transaksi Display Billing Document - FIORI Bussim

Gambar 9. merupakan contoh display billing document pada menu accounting yang dapat diakses oleh pengguna dengan memeriksa billing per periode dan status billing yang perlu ditampilkan.

\subsection{Hasil Analisis}

Adapun hasil analisis dibagi menjadi beberapa bagian yang meliputi: hasil analisis pengalaman pengguna pada aplikasi SAP-GUI, hasil analisis pengalaman pengguna pada aplikasi FIORI Bussim, Hasil analisis uji komparatif untuk ketiga domain pemahaman (kognitif, afektif dan psikomotorik).

\subsubsection{Analisis pengalaman pengguna pada SAP-GUI}

Kegiatan pengalaman pengguna untuk pre-test adalah kegiatan analisis pengalaman pengguna aplikasi SAPGUI dengan menilai sejauh mana pengalaman penggunaan SAP-GUI dengan menggunakan UEQ yang sudah dilengkapi dengan alat bantu pengujian yakni Data Analysis Tools. Setelah data kuesioner dari 132 responden direkam, data rekaman kemudian ditempatkan ke dalam Data Analysis Tools.

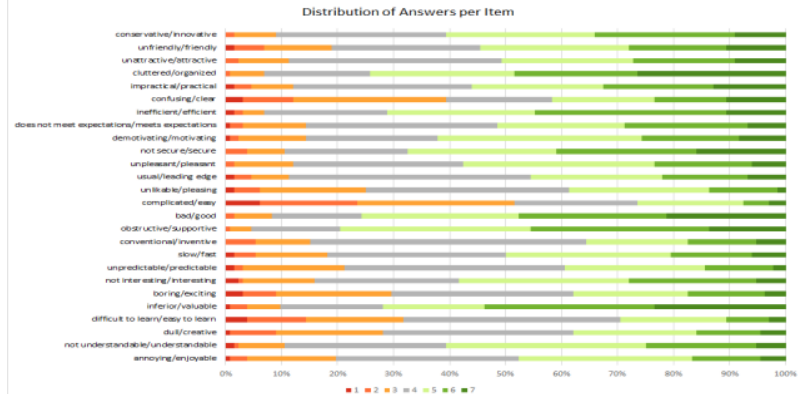

Gambar 10. Distribusi Jawaban kuesioner UEQ dari SAP-GUI

Gambar 10 menunjukkan sebaran/distribusi jawaban kuesioner UEQ dari SAP- GUI. Warna pada grafik menggambarkan persentase jawaban kuesioner responden pada item pertanyaan tertentu. 

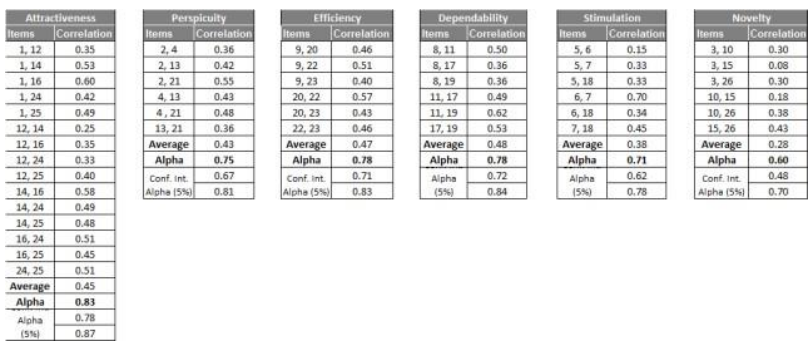

\section{Gambar 11. Nilai Koefisien Alpha Cronbach UEQ dari SAP-GUI}

Berdasarkan hasil output pada gambar 11 dapat dilihat bahwa nilai Cronbach's Alpha untuk setiap skala yang diujikan pada pada penelitian ini jika dibandingkan dengan nilai $r$ tabel dengan nilai $\mathrm{N}=132$ (pada distribusi nilai $\mathrm{r}$ tabel pada signifikansi 5\% maka diperoleh nilai $\mathrm{r}$ tabel sebesar 0.1710).

Tabel 1. Nilai Koefisien Alpha Cronbach UEQ dari SAP-GUI

\begin{tabular}{|l|c|c|}
\multicolumn{1}{|c|}{ Skala } & $\begin{array}{c}\text { Cronbach's } \\
\text { Alpha }\end{array}$ & Kesimpulan \\
\hline Attractiveness (daya tarik) & 0.83 & Reliabel \\
\hline Perspicuity (kejelasan) & 0.75 & Reliabel \\
\hline Efficiency (efisiensi), & 0.78 & Reliabel \\
\hline Dependability (ketepatan) & 0.78 & Reliabel \\
\hline Stimulation (stimulasi) & 0.71 & Reliabel \\
\hline Novelty (kebaruan) & 0.60 & Reliabel \\
\hline
\end{tabular}

Berdasarkan hasil pada Tabel 1, dapat disimpulkan bahwa keseluruhan item skala yang diuji pada penelitian ini sudah reliabel. Karena item yang akan digunakan pada penelitian sudah reliabel, maka hasil dari pengukuran pengalaman pengguna menggunakan UEQ dapat dilihat pada Gambar 12.

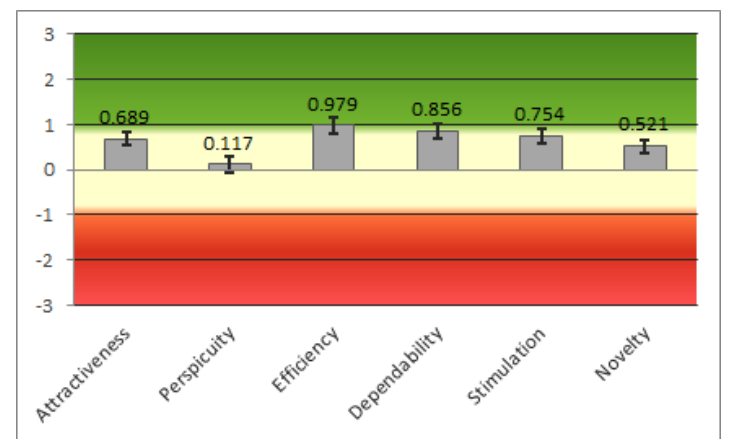

Gambar 12. Skala Pengukuran User Experience dari SAP-GUI

Pada gambar 12, dapat dilihat bahwa keeluruhan enam skala yang diuji bernilai positif karena hasil pengujian berada di atas skala 0 . Hasil ini dapat dikatakan bahwa pengalaman pengguna SAP-GUI memiliki penilaian yang positif.
Tabel 2. Hasil rata-rata dan varians Skala UEQ pada SAP-GUI UEQ Scales (Mean and Variances)

\begin{tabular}{|l|l|l|}
\hline Attractiveness & 0.689 & 0.80 \\
\hline Perspicuity & 0.117 & 1.07 \\
\hline Efficiency & 0.979 & 0.99 \\
\hline Dependability & 0.856 & 0.85 \\
\hline Stimulation & 0.754 & 0.90 \\
\hline Novelty & 0.521 & 0.66 \\
\hline
\end{tabular}

Tabel 2 memiliki interprestasi bahwa nilai rata- rata attractiveness (daya tarik) dan nilai rata-rata perspicuity (kejelasan) jika dibandingkan dengan benchmark berada pada skala "bad". Nilai rata-rata efficiency (efisiensi), Nilai rata-rata dependability (ketepatan), Nilai rata-rata stimulation (stimulasi) dan Nilai rata-rata novelty (kebaruan) berada pada skala below average atau di bawah rata-rata.

Tabel 3. Benchmark Interval untuk Skala UEQ untuk SAP-GUI

\begin{tabular}{|l|c|c|}
\hline \multicolumn{1}{|c|}{ Scale } & Mean & $\begin{array}{c}\text { Comparison to } \\
\text { benchmark }\end{array}$ \\
\hline Attractiveness & 0.69 & Bad \\
\hline Perspicuity & 0.12 & Bad \\
\hline Efficiency & 0.98 & Below Average \\
\hline Dependability & 0.86 & Below Average \\
\hline Stimulation & 0.75 & Below Average \\
\hline Novelty & 0.52 & Below Average \\
\hline
\end{tabular}

Gambaran yang lebih jelas tentang hasil interprestasi pada tabel 3 dapat dilihat pada gambar 15 dalam bentuk grafis.

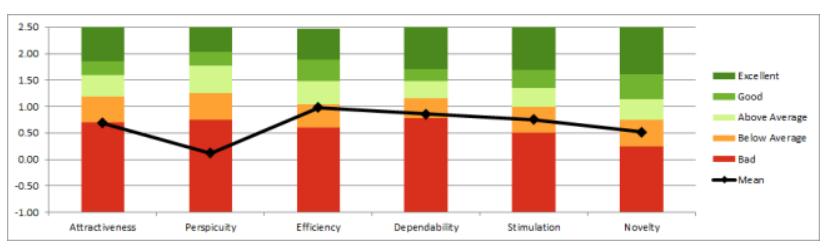

Gambar 13. Benchmark Hasil Pengukuran UEQ pada SAP-GUI

Gambar 13 memiliki interpretasi bahwa pada skala attractiveness (daya tarik) SAP-GUI dianggap menyusahkan, tidak nyaman, tidak atraktif dan tidak ramah pengguna sehingga perlu ada perhatian lebih lanjut. Pada skala efficiency (efisiensi) bernilai rendah pada kecepatan akses. Pada skala dependability (ketepatan) dinilai tidak dapat diprediksi dan tidak memenuhi ekspektasi. Dari sisi stimulation (stimulasi) SAP-GUI dianggap membosankan, tidak menarik dan kurang memotivasi pengguna. Dari sisi novelty (kebaruan) bernilai rendah dan dianggap monoton, konvensional dan tidak lazim. Sementara dari aspek perspicuity (kejelasan), SAP-GUI dinyatakan sulit dimengerti, sulit dipelajari, rumit dan membingungkan. 


\subsubsection{Hasil analisis pengalaman pengguna FIORI Bussim}

Kegiatan pengalaman pengguna untuk post-test adalah kegiatan analisis pengalaman pengguna aplikasi FIORI Bussim. Kegiatan analisis post-test adalah menilai sejauh mana pengalaman penggunaan FIORI Bussim. Kegiatan analisis pengalaman pengguna pada aplikasi FIORI Bussim juga menggunakan UEQ dengan alat bantu pengujian yakni Data Analysis Tools. Seperti halnya pada pre-test, data kuesioner dari 132 responden direkam dan ditempatkan ke dalam Data Analysis Tools untuk diproses. Adapun sebaran jawaban dari 132 responden dapat dilihat pada gambar 16.

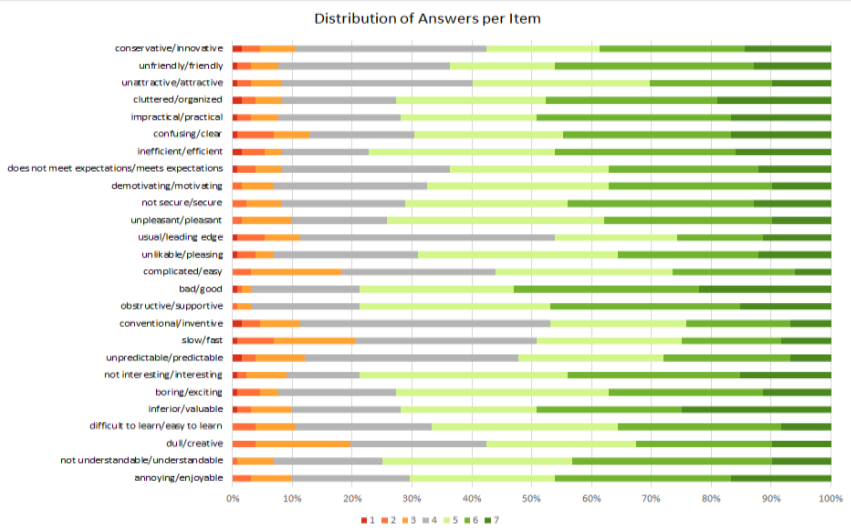

Gambar 14. Distribusi Jawaban kuesioner UEQ dari FIORI Bussim

Berdasarkan grafik pada gambar 14, dapat dilihat sebaran/distribusi jawaban kuesioner UEQ dari FIORI Bussim. Warna pada grafik menggambarkan persentase jawaban kuesioner responden pada item pertanyaan tertentu.
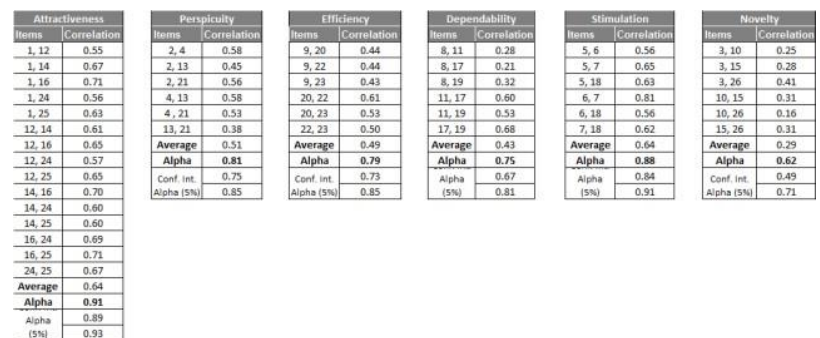

\section{Gambar 15. Nilai Koefisien Alpha Cronbach UEQ dari FIORI Bussim}

Berdasarkan hasil output pada gambar 15 dapat dilihat bahwa nilai Cronbach's Alpha untuk setiap skala yang diujikan pada penelitian ini jika dibandingkan dengan nilai $r$ tabel dengan nilai $\mathrm{N}=132$ (pada distribusi nilai $r$ tabel pada signifikansi 5\% maka diperoleh nilai $r$ tabel sebesar 0.1710).
Tabel 4. Skala Pengujian Bussim - Cronbach's Alpha

\begin{tabular}{|l|c|c|}
\hline \multicolumn{1}{|c|}{ Skala } & $\begin{array}{c}\text { Cronbach's } \\
\text { Alpha }\end{array}$ & Kesimpulan \\
\hline Attractiveness (daya tarik) & 0.91 & Reliabel \\
\hline Perspicuity (kejelasan) & 0.81 & Reliabel \\
\hline Efficiency (efisiensi), & 0.79 & Reliabel \\
\hline Dependability (ketepatan) & 0.75 & Reliabel \\
\hline Stimulation (stimulasi) & 0.88 & Reliabel \\
\hline Novelty (kebaruan) & 0.62 & Reliabel \\
\hline
\end{tabular}

Berdasarkan hasil pada tabel 4, dapat disimpulkan bahwa keseluruhan item skala yang diuji pada penelitian ini sudah reliabel. Karena item yang akan digunakan pada penelitian sudah reliabel, maka hasil dari pengukuran pengalaman pengguna menggunakan UEQ dapat dilihat pada gambar 16 .

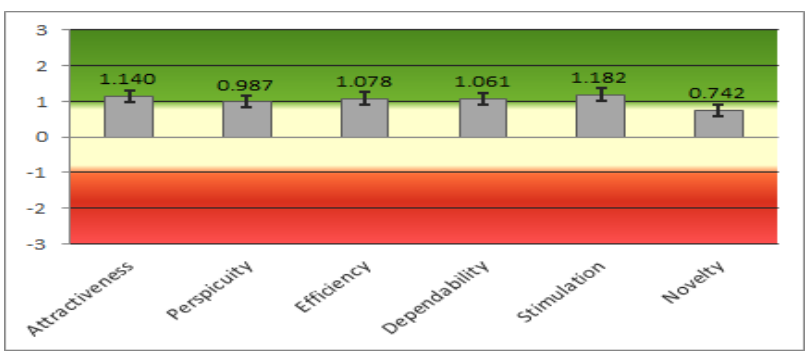

Gambar 16. Skala Pengukuran User Experience pada FIORI Bussim

Pada gambar 16, dapat dilihat bahwa keeluruhan enam skala yang diuji bernilai positif karena hasil pengujian berada di atas skala 0, dan bahkan lebih tinggi dari nilai pada SAP-GUI sebagai pre-test.

\section{Tabel 5. Hasil rata-rata dan Varians Skala UEQ pada} FIORI Bussim

\begin{tabular}{|l|c|c|}
\hline \multicolumn{3}{|c|}{ UEQ Scales (Mean and Variances) } \\
\hline Attractiveness & 1.140 & 1.04 \\
\hline Perspicuity & 0.987 & 0.97 \\
\hline Efficiency & 1.078 & 1.09 \\
\hline Dependability & 1.061 & 0.82 \\
\hline Stimulation & 1.182 & 1.13 \\
\hline Novelty & 0.742 & 0.80 \\
\hline
\end{tabular}

Hasil benchmark pada tabel 5 memiliki interprestasi bahwa nilai rata-rata attractiveness (daya tarik), nilai rata-rata perspicuity (kejelasan), nilai rata- rata dependability (ketepatan), dan nilai rata-rata novelty (kebaruan)jika dibandingkan dengan benchmark berada pada skala "below average" yang mana hal ini masih lebih baik dari hasil pada SAP-GUI. nilai rata-rata efficiency (efisiensi) dan nilai rata-rata stimulation (stimulasi) telah berada pada skala "above average" atau di atas rata-rata. Hal ini menunjukan skala yang lebih tinggi dibandingkan dengan SAP-GUI sebelumnya. 
Tabel 6. Benchmark Interval untuk Skala UEQ FIORI Bussim

\begin{tabular}{|l|c|c|}
\hline \multicolumn{1}{|c|}{ Scale } & Mean & $\begin{array}{c}\text { Comparison to } \\
\text { benchmark }\end{array}$ \\
\hline Attractiveness & 1.14 & Below Average \\
\hline Perspicuity & 0.99 & Below Average \\
\hline Efficiency & 1.08 & Above Average \\
\hline Dependability & 1.06 & Below Average \\
\hline Stimulation & 1.18 & Above Average \\
\hline Novelty & 0.74 & Below Average \\
\hline
\end{tabular}

Gambaran yang lebih jelas tentang hasil interprestasi pada tabel 6 dapat dilihat pada gambar 17 dalam bentuk grafis.

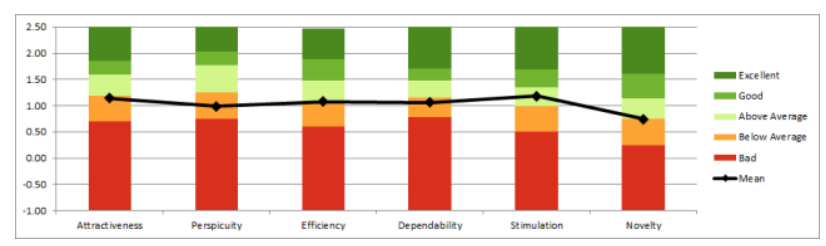

Gambar 17. Benchmark Hasil Pengukuran UEQ pada FIORI Bussim

Skala stimulation (stimulasi) meliputi valuable/inferior, boring/exciting, not interesting/interesting, dan motivating/demotivating telah memiliki nilai "above average" yang berarti sudah di atas rata-rata. Hal yang sama juga terdapat pada skala efficiency (efisiensi) yang memiliki poin antara lain: fast/slow, inefficient/efficient, impractical/practical, dan organized/cluttered yang juga telah memiliki nilai "above average". Walaupun begitu, hal ini masih membutuhkan peningkatan untuk mencapai skala "Good". Skala yang lain berada pada nilai di bawah ratarata, jika dilihat lebih lanjut maka skala attractiveness (daya tarik), perspicuity (kejelasan), efficiency (efisiensi), dependability (ketepatan), dan novelty (kebaruan) perlu diperhatikan dengan detail. Skala attractiveness (daya tarik) memiliki poin penting antara lain: annoying/enjoyable, good/bad, unlikeable/pleasing, unpleasant/pleasant, attractive/unattractive, dan friendly/unfriendly. Selanjutnya adalah skala perspicuity (kejelasan). Pada skala ini, hal yang harus diperhatikan adalah not understandable/understandable, easy to learn/difficult to learn, complicated/easy, dan clear/confusing. Kemudian skala dependability (ketepatan) yang memuat hal-hal antara lain: unpredictable/predictable, obstructive/supportive, secure/not secure, dan meet expectations/does not meet expectations. Dan yang terakhir adalah skala novelty (kebaruan) yang memiliki poin antara lain: creative/dull, inventive/conventional, usual/leading edge, conservative/innovative. Keseluruhan skala ini perlu mendapatkan perhatian lebih karena masih berada pada skala "Below Average".

\subsubsection{Hasil Analisis Uji Komparatif Untuk Domain Pemahaman}

Hasil uji komparatif untuk domain pemahaman juga turut dilakukan. Uji komparatif pada tabel 6 dilaksanakan dengan menggunakan Uji Wilcoxon. Pemahaman dinilai dengan jumlah responden yang sama yakni sebanyak 132 orang responden. Dari keseluruhan jumlah responden, 132 data yang ada baik untuk pre-test dan post-test dinyatakan valid. Valid dalam berarti bahwa semua kuesioner yang akan diproses telah terisi dengan lengkap.

\section{Tabel 6. Case Processing Summary untuk Pre-Test dan Post-Test}

\begin{tabular}{llr|r} 
& & $\mathrm{N}$ & \multicolumn{1}{c}{$\%$} \\
\hline \multirow{2}{*}{ Cases } & Valid & 132 & 100.0 \\
\cline { 2 - 4 } & Excluded $^{3}$ & 0 & .0 \\
\cline { 2 - 4 } & Total & 132 & 100.0 \\
\hline
\end{tabular}

Dari tabel 7, dapat diketahui bahwa item pertanyaan untuk kategori pemahaman pre-test terdapat 18 item pertanyaan dengan nilai Cronbach's Alpha sebesar 0.952. Seperti yang telah diuraikan sebelumnya di atas bahwa Joko Widyanto (2010) menjelaskan bahwa dasar pengambilan keputusan dalam uji reliabilitas adalah reliabel jika lebih nilai Cronbach's Alpha lebih besar dari r tabel. Hasil pengujian pre-test ini adalah reliabel karena nilai 0.952 lebih besar dari 0.468 (nilai $r$ tabel signifikansi $5 \%$ ).

Tabel 7. Statistik Reliabilitas untuk Pre-Test

\begin{tabular}{r|r}
\multicolumn{1}{c|}{$\begin{array}{c}\text { Cronbach's } \\
\text { Alpha }\end{array}$} & N of Items \\
\hline .952 & 18 \\
\hline
\end{tabular}

Jika dibandingkan dengan setiap item, nilai Cronbach's Alpha per item juga masih reliabel. Nilai ini dapat dilihat pada Tabel 8 . 
Tabel 8. Item Total Statistics untuk Pre-Test

\begin{tabular}{|c|c|c|c|c|}
\hline & $\begin{array}{l}\text { Scale Mean if } \\
\text { Item Deleted }\end{array}$ & $\begin{array}{l}\text { Scale Variance } \\
\text { if Item Deleted }\end{array}$ & $\begin{array}{c}\text { Correc ted Item- } \\
\text { Total } \\
\text { Correlation }\end{array}$ & $\begin{array}{c}\text { Cronbach's } \\
\text { Alpha if Item } \\
\text { Deleted }\end{array}$ \\
\hline a1 & 61.05 & 240.044 & .640 & .951 \\
\hline a2 & 61.32 & 234.264 & .850 & .947 \\
\hline a3 & 61.52 & 239.427 & .737 & .949 \\
\hline a4 & 61.30 & 241.923 & .778 & .948 \\
\hline a5 & 61.31 & 242.338 & .764 & .948 \\
\hline a6 & 61.03 & 242.824 & .712 & .949 \\
\hline b1 & 61.58 & 240.353 & .753 & .948 \\
\hline b2 & 61.68 & 245.104 & .662 & .950 \\
\hline b3 & 62.55 & 249.669 & .524 & .952 \\
\hline b4 & 61.48 & 238.832 & .761 & .948 \\
\hline b5 & 61.91 & 243.885 & .533 & .953 \\
\hline c1 & 61.53 & 247.472 & .602 & .951 \\
\hline c2 & 61.45 & 236.815 & .792 & .948 \\
\hline c3 & 61.08 & 237.811 & .820 & .947 \\
\hline c4 & 61.34 & 241.448 & .757 & .948 \\
\hline c5 & 60.70 & 241.373 & .703 & .949 \\
\hline c6 & 61.29 & 243.229 & .703 & .949 \\
\hline c7 & 61.27 & 242.532 & .670 & .950 \\
\hline
\end{tabular}

Dari Tabel 9, dapat diketahui bahwa item pertanyaan untuk kategori pemahaman post-test terdapat 18 item pertanyaan dengan nilai Cronbach's Alpha sebesar 0.966. Seperti yang telah diuraikan sebelumnya di atas bahwa Joko Widyanto (2010) menjelaskan bahwa dasar pengambilan keputusan dalam uji reliabilitas adalah reliabel jika lebih nilai Cronbach's Alpha lebih besar dari $\mathrm{r}$ tabel. Hasil pengujian post-test ini adalah reliabel karena nilai 0.966 lebih besar dari 0.468 (nilai $\mathrm{r}$ tabel signifikansi 5\%).

Tabel 9. Statistik reliabilitas untuk post-test

\begin{tabular}{r|r}
\multicolumn{1}{c}{$\begin{array}{c}\text { Cronbach's } \\
\text { Alpha }\end{array}$} & N of ltems \\
\hline 966 & 18 \\
\hline
\end{tabular}

Jika dibandingkan dengan setiap item, nilai Cronbach's Alpha per item juga masih reliabel. Nilai ini dapat dilihat pada Tabel 10.
Tabel 10. Item Total Statistics untuk Post-Test

\begin{tabular}{|c|c|c|c|c|}
\hline & $\begin{array}{l}\text { Scale Mean if } \\
\text { Item Deleted }\end{array}$ & $\begin{array}{l}\text { Scale Variance } \\
\text { if ltem Delesed }\end{array}$ & $\begin{array}{c}\text { Correcied item- } \\
\text { Total } \\
\text { Comelation } \\
\end{array}$ & $\begin{array}{c}\text { Cronbach's } \\
\text { Alpha if Item } \\
\text { Deleted }\end{array}$ \\
\hline a1 & 50.50 & 257.595 & .736 & .964 \\
\hline a2 & 50.58 & 255.558 & 802 & .964 \\
\hline as & 50.48 & 256.175 & 817 & 963 \\
\hline a4 & 50.36 & 259.513 & .783 & .964 \\
\hline as & 5029 & 255764 & 809 & .963 \\
\hline a6 & 50.26 & 259.551 & .723 & .965 \\
\hline b1 & 50.52 & 256053 & .760 & .964 \\
\hline b2 & 50.53 & 254785 & 825 & .963 \\
\hline b3 & 50.92 & 260926 & .662 & .965 \\
\hline b4 & 50.55 & 255.409 & 818 & .963 \\
\hline b5 & 50.50 & 256924 & .689 & .965 \\
\hline c1 & 50.33 & 260087 & .727 & .965 \\
\hline$c 2$ & 50.58 & 255819 & 837 & .963 \\
\hline e3 & 50.24 & 256.368 & .772 & .964 \\
\hline C4 & 50.36 & 255834 & .788 & .964 \\
\hline C5 & 50.00 & 257.344 & .730 & .965 \\
\hline$c 6$ & 50.35 & 254656 & 813 & .963 \\
\hline c7 & 5021 & 255970 & 760 & .964 \\
\hline
\end{tabular}

Adapun hasil analisis uji komparatif untuk domain pemahaman secara rinci dapat dilihat pada Tabel 11.

Tabel 11. Hasil Uji Wilcoxon

\begin{tabular}{llr|r|r} 
& & $N$ & Mean Rank & Sum of Ranks \\
\hline post_c - pre_c & Negative Ranks & $102^{\mathrm{a}}$ & 65.87 & 6718.50 \\
\cline { 2 - 5 } & Positive Ranks & $18^{\mathrm{b}}$ & 30.08 & 541.50 \\
\cline { 2 - 5 } & Ties & $12^{\mathrm{c}}$ & & \\
\cline { 2 - 5 } & Total & 132 & & \\
\hline post_a - pre_a & Negative Ranks & $78^{\mathrm{d}}$ & 60.96 & 4754.50 \\
\cline { 2 - 5 } & Positive Ranks & $32^{\mathrm{e}}$ & 42.20 & 1350.50 \\
\cline { 2 - 5 } & Ties & $22^{\mathrm{f}}$ & & \\
\cline { 2 - 5 } & Total & 132 & & \\
\hline \multirow{2}{*}{ post_p - pre_p } & Negative Ranks & $96^{\mathrm{a}}$ & 69.86 & 6706.50 \\
\cline { 2 - 5 } & Positive Ranks & $26^{\mathrm{h}}$ & 30.63 & 796.50 \\
\cline { 2 - 5 } & Ties & $10^{\mathrm{j}}$ & & \\
\cline { 2 - 5 } & Total & 132 & & \\
\hline
\end{tabular}

Tabel 12 menunjukkan beberapa kategori yakni "negative rank" yang berarti nilai pre-test lebih besar dari post-test, "positive rank" yang berarti nilai pre-test lebih kecil dari post-test dan "ties" yang berarti nilai pretest sama besarnya dengan nilai post-test. Dari hasil pengujian, dapat diketahui bahwa dari domain kognitif, terdapat 102 orang responden yang nilai rata-rata kognitif dari pre-test lebih besar dibandingkan dengan post-test. Hanya 18 orang yang nilai rata-rata kognitifnya meningkat (positive rank) pada post-test. Dan terdapat 12 orang yang sama besar kemampuan kognitifnya untuk pre-test dan post-test. Untuk domain afektif, fenomena yang sama juga terjadi. Terdapat 78 orang responden yang nilai rata-rata afektif dari pre-test lebih besar dibandingkan dengan post-test (negative rank). Hanya 32 orang responden yang nilai rata-rata afektif dari post-test lebih besar dari pre-test (positive rank). Terdapat 22 orang responden yang nilai rata-rata afektif dari post-test 
dan pre-test sama besarnya (ties). Untuk domain psikomotorik, hal yang sama juga terjadi. Terdapat 96 orang responden dengan kategori "negative rank" yang mana nilai rata-rata psikomotorik pre-test lebih tinggi dibandingkan dengan post-test, 26 orang dengan "positive rank" dimana nilai rata-rata psikomotorik posttest lebih besar dari pre-test dan 10 orang dengan kategori "ties" dimana nilai rata-rata psikomotorik pretest sama besarnya dengan post-test. Keseluruhan hasil test menunjukkan bahwa terdapat perbedaan yang bermakna antara pre-test dan post-test karena nilai asymp sig 2 tailed lebih kecil dari batas kritis penelitian yakni 0,05 .

Tabel 12. Hasil Uji Statistik untuk Pre-Test Dan PostTest

\begin{tabular}{lrr|r|r} 
& post_c - pre c & post_a - pre_a & post_p-pre_p \\
\hline$Z$ & $-8.094^{\mathrm{b}}$ & $-5.090^{\mathrm{b}}$ & $-7.556^{\mathrm{b}}$ \\
\hline Asymp. Sig. (2-tailed) & .000 & .000 & .000 \\
\hline
\end{tabular}

Berdasarkan hasil yang telah didapatkan di atas hal yang perlu diperhatikan.

1. Hasil pengujian menggunakan UEQ pada SAP-GUI dan FIORI Bussim menunjukkan bahwa nilai pengalaman penggunaan SAP-GUI lebih rendah dibandingkan dengan FIORI Bussim. Hal ini dapat diinterpretasikan bahwa FIORI Bussim memiliki pengalaman penggunaan yang lebih baik terutama dari aspek efisiensi dan stimulasi. SAP-GUI masih perlu meningkatkan pengalaman penggunaannya terutama pada aspek attractiveness (daya tarik) dan perspicuity (kejelasan)

2. Nilai pengujian terhadap domain pemahaman yang dilihat dari domain kognitif, afektif dan psikomotorik menunjukkan bahwa lebih banyak responden yang mengalami penurunan dibandingkan peningkatan positif. Hal ini berarti setelah penggunaan FIORI Bussim tidak menghasilkan adanya peningkatan pemahaman malah sebaliknya penurunan.

3. Pengalaman penggunaan yang lebih baik dari FIORI Bussim ternyata tidak membuat tingkat pemahaman menjadi lebih baik.

Namun demikian, penelitian ini masih memiliki keterbatasan.

1. Pembelajaran FIORI Bussim dilakukan selama beberapa kali pertemuan perkuliahan. kegiatan pengukuran pengalaman pengguna dilakukan pada saat pembelajaran FIORI Bussim telah selesai dilakukan. Akan tetapi saat pembelajaran tengah dilakukan, terdapat update terhadap aplikasi FIORI Bussim. Pengukuran pengalaman pengguna yang dilakukan dalam penelitian adalah pengalaman pengguna terhadap FIORI Bussim setelah update. Pengukuran pengalaman pengguna aplikasi FIORI Bussim belum melibatkan pengalaman pengguna sebelum update.
2. Penelitian ini juga belum meninjau aspek dari aplikasi FIORI Bussim yang menyebabkan penurunan pemahaman pengguna tentang proses bisnis yang terintegrasi dalam aplikasi SAP.

\section{KESIMPULAN}

Hasil pengujian menggunakan UEQ pada SAP-GUI dan FIORI Bussim dengan jumlah responden sebanyak 132 orang menunjukkan bahwa nilai pengalaman penggunaan FIORI Bussim lebih baik dari SAP-GUI.

Nilai pengujian terhadap domain pemahaman yang dilihat dari domain kognitif, afektif dan psikomotorik menunjukkan bahwa lebih banyak responden yang mengalami penurunan dibandingkan peningkatan positif. Pengalaman penggunaan yang lebih baik dari FIORI Bussim ternyata tidak membuat tingkat pemahaman terhadap proses bisnis dalam SAP menjadi lebih baik.

\section{SARAN}

Saran yang dapat diberikan untuk penelitian selanjutnya adalah penelitian ini perlu dilakukan kembali dengan metode pengujian yang sama dan kondisi pembelajaran FIORI Bussim pada saat aplikasi dalam kondisi yang lebih stabil. untuk penelitian dengan judul atau topik yang mengacu kepada penelitian ini kedepannya dapat lebih baik lagi.

\section{DAFTAR PUSTAKA}

Adinegoro, A.L.T., Rokhmawati, R.I. and Az-Zahra, H.M., 2018. Analisis Pengalaman Pengguna pada Website E-commerce Dengan Menggunakan Usability Testing dan User Experience Questionnaire (UEQ)(Studi pada Lazada. co. id, Blibli. com dan JD. id). Jurnal Pengembangan Teknologi Informasi dan Ilmu Komputer e-ISSN, 2548, p.964X.

Hoque, M.E., 2016. Three Domains of Learning: Cognitive, Affective and Psychomotor. The Journal of EFL Education and Research, 2(2), pp.45-52.

Izabal, S.V., Aknuranda, I. and Az-Zahra, H.M., 2018. Evaluasi dan Perbaikan User Experience Menggunakan User Experience Questionnaire (UEQ) dan Focus Group Discussion (FGD) pada Situs Web FILKOM Apps Mahasiswa Fakultas Ilmu Komputer Universitas Brawijaya. Jurnal Pengembangan Teknologi Informasi dan Ilmu Komputer e-ISSN, 2548, p.964X.

Laugwitz, B., Held, T. and Schrepp, M., 2008, November. Construction and evaluation of a user experience questionnaire. In Symposium of the Austrian HCI and Usability Engineering Group (pp. 63-76). Springer, Berlin, Heidelberg.

Lukita, K.A., Galinium, M. and Purnama, J., 2018, March. User Experience Analysis of an ECommerce Website Using User Experience Questionnaire (UEQ) Framework. In Prosiding Seminar Nasional Pakar (pp. 347-355). 
Rauschenberger, M., Schrepp, M., Cota, M.P., Olschner, S. and Thomaschewski, J., 2013. Efficient measurement of the user experience of interactive products. How to use the user experience questionnaire (UEQ). Example: Spanish language version. International Journal of Artificial Intelligence and Interactive Multimedia. 2013; 2 (1): PP.39-45.

Santoso, H.B., Schrepp, M., Isal, R., Utomo, A.Y. and Priyogi, B., 2016. Measuring user experience of the student-centered e-learning environment. Journal of Educators Online, 13(1), pp.58-79.

Santoso, H.B., Schrepp, M., Isal, R.Y.K., Utomo, A.Y. andPriyogi, B., 2016. User experience questionnaire: development of an Indonesian version and its usage for product evaluation. The Journal of Educators Online JEO, 13(1), pp.58-79.

Sularsa, A., Prihatmanto, A.S. and Nugroho, E., 2015. Evaluasi User Experiences Produk iDigital Museum dengan Menggunakan UEQ. Jurnal Teknologi Informasi, 2(2), pp.56-62.

Tractinsky, N., Katz, A.S. and Ikar, D., 2000. What is beautiful is usable. Interacting with computers, 13(2), pp.127-145. 